\title{
Fiscal forecast errors: governments vs independent agencies?*
}

\author{
Rossana Merola \\ OECD
}

\author{
Javier J. Pérez \\ Bank of Spain
}

May 1, 2012

\begin{abstract}
The fact that the literature tends to find pro-deficit biases in national fiscal projections has led to a growing claim in the academic and policy arenas for the need to introduce independent forecasts in the fiscal domain, prepared by independent agencies, like the European Commission in the case of Europe. Within this debate the aim of this paper is to test: (i) is the forecast performance record of governments indeed worse than that of international organizations?; (ii) are fiscal projections prepared by international organizations free from political economy distortions? The answer to these two questions is negative: our results, based on real-time data for 15 European countries over the period 1999-2007, point to the rejection of the two hypotheses under scrutiny. We rationalize the empirical analysis in the framework of a model in which an independent agency tries to minimize the distance to the government forecast. We exploit the idea that the government's information set includes private information not available to outside forecasters. We show how such a framework can rationalize the observed empirical evidence and give some rationale to the strengthening of sanctions to misbehaving governments along the lines of the recent proposals suggested in European fora.
\end{abstract}

JEL Classification: H6; E62; C53.

Keywords: Forecast errors; fiscal policies; fiscal forecasting; political economy.

*The views expressed in this paper are the authors' and do not necessarily reflect those of the Bank of Spain, the Eurosystem or the OECD. We thank Marta Botella and Laura Fernández-Caballero for excellent research assistance. We also thank participants at the International Symposium on Forecasting (San Diego), the ESCB-Working Group on Public Finance Meeting (Cyprus), the Banco de España seminar, the CESiFO Workshop on Political Economy (Dresden) and the European Commission, in particular Michael Berlemann, Enrique Moral, Lucio Pench, and Ernesto Villanueva, for helpful comments. Correspondence to: Javier J. Pérez (javierperez@bde.es), Servicio de Estudios, Banco de España, c/Alcalá 48, 28014 Madrid, Spain. 


\section{Introduction}

Should the role of preparing budgetary projections be delegated to an independent agency? This debate has been recently spurred in Europe by many voices, given the enormous public deficit and debt levels currently held by many European Union (EU) countries. In fact, planned government deficit turned out to exceed recurrently budgetary plans by a huge magnitude in recent years. For example, as late as October 2008 the public deficits estimated for 2008 by many European countries missed by some 2 percentage points of GDP the afterwards released figures for 2008. A similar situation occurred in 2009 and 2010, leading many countries to register record high deficits. Explanatory factors for this misalignments include large GDP shocks and fiscal stimulus packages adopted on the run, but beyond this, also lack of both transparency and a realistic account of facts. As short-run budgetary targets were missed by far, medium run plans were revised quickly and resulted in a fast decline of the credibility of Europe's fiscal framework, namely the Stability and Growth Pact (SGP). As a consequence, right now, many European countries are embarking in widespread mediumterm fiscal consolidation packages, that require adherence to strict budgetary targets for long periods of time. In parallel, there is an ongoing policy debate on the need to strengthen economic governance in the EU, in particular with regard to fiscal framework, that has already been materialized in a number of reform proposals. ${ }^{1}$

The recent deterioration of public deficits and the lack of accuracy of fiscal projections is not an event confined to the current juncture. Indeed, a great deal of the literature has analyzed in the recent past the potential bias the political and institutional process might have on government revenue and spending forecasts, ${ }^{2}$ and the nature and properties of forecast errors within national states. ${ }^{3}$ For the case of European countries, this literature

\footnotetext{
${ }^{1}$ On the importance of the design of fiscal rules and forms of governance in EU countries see Hallerberg et al. (2007). For the discussion on EU's fiscal framework weaknesses and needs for reform see, for example, Larch, van den Noord and Jonung (2010). For the most recent approved and ongoing reforms and/or agreements, see EC's webpage dedicated to EU economic governance ("http://ec.europa.eu/economy_finance/economic_governance/index_en.htm").

${ }^{2}$ See for example von Hagen and Harden (1994), Auerbach (1995, 1996), Plesko (1988), Feenberg et al. (1988), Bretschneider et al. (1989), Shkurti and Winefordner (1989), Cassidy et al. (1989), Bruck and Stephan (2006), Jonung and Larch (2006), Pina and Venes (2011), Boylan (2008), Beetsma et al. (2009), von Hagen (2010).

${ }^{3}$ See Cohen and Follete (2002), Campbell and Ghysels (1995), Jennes and Arabackyj (1998), Auerbach (1999), Gentry (1989), Fullerton (1989), Melliss (1996), Mellis and Whittaker (1998), Baguestani and Mc-
} 
tends to find evidence in favor of the existence of systematic political and institutional biases in revenue forecasting, while the evidence for the US is mixed, depending on the institutional coverage of the analysis (Federal government or States). ${ }^{4}$

One particular aspect under discussion in the policy fora is the proposal to introduce independent forecasts in the fiscal domain (Debrun et al. 2009; Leeper 2009; Wyplosz 2008; Jonung and Larch 2006; European Commission 2006) prepared by independent agencies. These independent agencies can be for example national councils or intergovernmental agencies. As regards the latter option, in the case of EU countries, some authors have advocated that the EC should have some role as the "independent agency" preparing budgetary and/or macroeconomic projections, given that fiscal forecasts by national authorities are scrutinized by the European Commission (EC) in application of EU's fiscal rules framework (the SGP $)^{5}$. But, which is the relative track record of international agencies' forecasts? Their forecast record on GDP and inflation seems to have been reasonable in terms of size and directional accuracy, ${ }^{6}$ even though some works point to a worse accuracy record than that of private sector analysts. ${ }^{7}$

Beyond this, for the issue at stake - public deficit forecasts - the relevant question is: has the track record of international agencies' forecasts been better than the one of national governments? In this particular respect the literature is almost silent. There are no studies that compare the accuracy of government forecasts and fiscal forecast error's determinants Nown (1992), Mhleisen et al. (2005), Moulin and Wierts (2006), Strauch et al. (2004), Frankel (2011).

${ }^{4}$ As Auerbach (1999) argues, if the costs of forecast errors were symmetric (i.e. if positive errors were as bad as negative errors), the forecasts should present no systematic bias (i.e. on average the forecast error should not differ significantly from zero). There are, however, reasons to presume that the loss function of governments may not be symmetric. Thus a kind of bias in fiscal forecasts could be optimal. For instance, a government would tend to favor a deficit when the loss of an underestimation is greater (for example, a conservative, stability oriented government, see Bretschneider et al. 1989). Public authorities may have an interest in presenting a pessimistic forecast to build in a safety margin that would allow them to meet budgetary targets, also in case of revenue or expenditure slippages. The literature in question finds mixed evidence for political economy-based explanations of this sort. See Leal et al. (2008) for a broad survey of the issues discussed here.

${ }^{5}$ See Buti and van den Noord (2004) or von Haguen (2003).

${ }^{6}$ Dreher et al. (2008), Melender et al. (2007), Aldenhoff (2007), Timmermann (2007), Artis and Marcellino (1998, 2001), Pons (2000), Keereman (1999).

${ }^{7}$ See Batchelor (2001) or Blix et al. (2001). Also, in a related paper Poplawski-Ribeiro and Rülke (2010) analyze how the introduction and reform of the SGP have changed the expectations of financial market experts on fiscal policies for the four largest EU countries. They proxy financial market expectations by Consensus Economic Forecasts, and also look at the link of the former with EC's and national governments' public deficit forecasts. 
with those produced by international organizations for a given country. Available papers typically focus on projections prepared by governments, while some analyze forecasts prepared by international agencies (the EC, the OECD, the IMF or some of them). In addition, different studies are difficult to compare as they tend to use different econometric methods, different sample periods, focus the analysis in one particular vintage of forecasts, and pursue different approaches as regards the role of institutions and political economy determinants of fiscal projections. ${ }^{8}$

The fact that some international organizations like the EC, the OECD or the IMF do publish fiscal forecasts and have been doing so for long periods of times provides a natural laboratory to analyze their track record against that of national governments. From a theoretical point of view independent agencies should not display the biases typically found in government's fiscal forecasts, once accounting for errors in macro forecasts. ${ }^{9}{ }^{10}$ On the contrary, one may claim that information matters when preparing budgetary projections, as outside forecasts (from independent organizations) might tend to be less accurate than inside forecasts (from staff of the relevant organizations, like for example the Ministry of Finance or the Treasury), as found by Grizzle and Klay (1994) for the US states. Along these lines, one could also argue that international organizations do not have the resources to make its own forecasts for each individual member state and, therefore, must rely heavily on the information conveyed to it by the member states. ${ }^{11}$

In our paper we provide homogeneous and comprehensive empirical evidence pointing to the fact that international agencies' track record of fiscal forecasts do present bias and correlation with electoral cycles in EU countries. We try to rationalize the empirical anal-

\footnotetext{
${ }^{8}$ von Hagen (2010), Melander et al. (2007), Pina and Venes (2011), Brück and Stephan (2006), Annet (2006), Strauch et al. (2004), Artis and Marcellino (2001), Keereman (1999).

${ }^{9}$ Nonetheless, for IMF macroeconomic forecasts Aldenhoff (2007) reveals significant correlation with election dates in the US. For the EU, the descriptive analysis provided by Marinheiro (2010) shows that the relative performance of EC's with respect to government's GDP growth forecasts is rather mixed, even though, overall, year-ahead EC's growth forecasts tend to outperform government forecasts at that horizon.

${ }^{10}$ Artis and Marcellino (2001) argue that the OECD is freer from the political pressures of EU governments than the EC. Poplawski-Ribeiro and Rülke (2010), though, do not find the data supporting the latter hypothesis. Christodoulakis and Mamatzakis (2009) note that even though year-ahead government balance forecasts are symmetric for most EU-15 countries, there seemed to be some leeway against breaching the $3 \%$ threshold value, especially for higher debt countries.

${ }^{11}$ This argument is taken from von Hagen (2010), that applies it to fiscal forecasts prepared by the European Commission.
} 
ysis in the framework of a model in which the independent (international) agency tries to minimize the distance to government forecasts. We exploit the idea that government's information set includes private information (better access to the relevant data, information on policy measures, etc) not available to outside forecasters (like the EC). When preparing their fiscal projections, EC staff tries to grasp as much private information as possible from government's, while at the same time face a "signal extraction problem" because they have to disentangle "political biases" from genuine "private information".

In the main, empirical part of the paper we test two basic hypotheses. First hypothesis: is the forecast performance of governments as regards budgetary projections worse than that of international organizations (like the EC and the OECD)? Second hypothesis, are fiscal projections prepared by international organizations free from the political economy distortions typically found for national fiscal projections?

Quite importantly, to answer these questions we use a common methodology (same econometric method, same empirical specification) to look at alternative datasets, over the same sample period. We build up a large real-time dataset covering fiscal forecasts: (i) that are prepared by national governments (GOV), the EC and the OECD; (ii) for 15 European countries; (iii) for two forecast origins per year, spring and autumn of each year; (iv) for two forecast horizons (current year and one year ahead). We focus on the sample 1999-2007 to eliminate two important sources of distortions: (i) the changes in statistical standards that did occur in the preceding period (ESA79-ESA95 changeover); (ii) the EMU convergence process. Thus, we analyze a period with a common monetary policy regime (Eurosystem), and a common fiscal policy regime (SGP).

Our main empirical results are as follows. First, we find that the influence of electoral cycles on fiscal forecasts is significant in the case of GOV, EC and OECD. Electoral cycles contribute to optimistic public deficit forecasts. At the same time we find that the order of political independence is such that: OECD and EC $\succ$ GOV. Second, GDP errors influence significantly government deficit errors, in such a way that a negative growth shock produces ex-post optimistic revenue and deficit forecasts. GOV projections are found to be less reactive to the economic cycle (more judgemental) than EC and OECD fiscal forecasts. Third, a dummy for government fiscal projections in the pool of all datasets does not show up sig- 
nificantly different from zero, but it does show up as significant and negative (i.e. consistent with a higher deficit bias) in good times. Fourth, when the sample is spilt into good and bad times we find that elections influence public deficit forecast errors more strongly in good than in bad times, and that EC/OECD deficit projections become "more independent" in good times than in bad times.

The rest of the paper is organized as follows. In Section 2 we pose a political economy model to frame the subsequent empirical analysis. In Section 3 we discuss the empirical literature for the EU and describe the data and variables used in the empirical analysis. The is done in Section 4, where we pose the hypotheses to be tested, the empirical methodology and the main results. Finally, in Section 5 we present some conclusions.

\section{Some political economy considerations}

When facing from a theoretical point of view the linkages between government's fiscal forecasts and fiscal forecasts by independent agencies, some remarks have to be done. First, on the fiscal domain governments usually have access to more information than outside forecasters. For example, governments have advanced information on tax developments, the impact of planned fiscal measures or information on the implementation of spending plans. In many cases, some levels of government for which few published short-term fiscal information is available to outsiders within a reasonable time lag, like regional and local governments, do account for a substantial share of general government spending.

Second, the methods used by government's officials and independent agencies' Staff for revenue and spending estimation and forecasting, can differ. Government forecasts are prepared for all budgetary items and thus the approach is a bottom-up one with a high level of disaggregation, while fiscal forecasts by international organizations are prepared for fewer, more aggregated budgetary items (see Leal et al. 2008). At the same time, it is typically the case that the forecasting methods used by international agencies to forecast those more aggregated items tend to be more sophisticated.

Third, governments can influence forecasts prepared by international organizations, as national countries are shareholders of the organizations and thus have the possibility to know those forecasts in advance and discuss them with the Staff of the relevant organization; for 
example, IMF Article IV reports (country reviews) acknowledge the discussions with government officials and signal discrepancies in assessment. Finally, given the latter point, the fact that government's do have access to private information, and given also that international organization tend to be shorter of specialized Staff than national organizations, intergovernmental agencies' reports usually have to clearly explain the reasons for any departure from national government's forecasts.

With all these considerations in mind, it is fair to conceive the preparation of fiscal forecasts by independent agencies, from a conceptual point of view, as an exercise that tries to minimize a certain loss function of the distance to government's projections. Auerbach (1999) develops a model for a different problem than ours, whose main elements can be adapted in such a way that it is suitable for the discussion of the issues at hand here. Let $\Omega$ be the information set commonly observed by all fiscal forecasters, be them government officials or international agencies' Staff. Let $x$ be the variable to be forecast, say government deficit, revenue or expenditure. Then, the best prediction that can be done using a commonly understood forecast methodology is:

$$
\bar{x}_{\Omega}=E(x / \Omega)
$$

Now, let $\Pi$ be the information set comprising some private information known only by the government, where $\Omega \subset \Pi$. The best forecast prepared by the government is then:

$$
\bar{x}_{\Pi}=E(x / \Pi)
$$

and the associated forecast error is: $\epsilon=x-\bar{x}_{\Pi}$, where $\epsilon$ is a stochastic, possibly zero mean, error. If $\Pi$ were the true information set, $\epsilon$ would have zero mean. Given that the international agency (call it EC) only has partial access to government's private information, its forecast of $x$, given by (1), do present an additional, independent error term, $\nu$, so that $x-\bar{x}_{\Omega}=\nu+\epsilon .{ }^{12}$

Now, the government has two options. First, it can prepare the best possible forecast given its information set, $\bar{x}_{\Pi}$, as in $(2)$, in which case it would minimize a loss function of the

\footnotetext{
${ }^{12}$ Under the assumption that the technical forecast error $\epsilon$ is the same for the two institutions. In practice, two different $\epsilon$-type error could be considered, due to differences in forecasting methods. This is immaterial for the discussion at hand and thus it is left aside at this point.
} 
sort $\Lambda_{1}=E\left[\bar{x}_{\Pi}-x / \Pi\right]^{2}$. Now, as signalled by the literature on politically-motivated fiscal forecast biases, the government has a second option. It can aim at minimizing a loss function of this sort: $\Lambda_{2}=E\left[\gamma\left(\bar{x}_{\Pi}-x-\theta\right) / \Pi\right]^{2}$, where $\theta$ is a bias included in the forecasting process for political reasons, and $\gamma$ a penalty parameter, given that producing systematically biased forecasts can also have costs for the government. In this case, the best (constrained) forecast prepared by the government would be $\bar{x}_{\Pi}^{\theta}=\bar{x}_{\Pi}+\theta$ so that the associated forecast error would be:

$$
x-\bar{x}_{\Pi}^{\theta}=\epsilon+\theta
$$

where $\theta$ is a negative parameter if $x$ do refer to the government deficit. The independent agency, in turn, has also two options. First, it can prepare a fully independent forecast that can be compared ex-post with government's forecast. In this case, though, the independent agency would loose any access to government's private information. Then, the second option is to try to minimize the distance to the forecast of the government, so that the error term $\nu$ is minimized; in actual situations, the second alternative tends to be the preferred one, not only because of the existence of private information on the side of governments, but also due to institutional and policy constraints, as discussed above. Thus, the independent agency knows that its forecast error is:

$$
x-\bar{x}_{\Omega}=\nu+\theta+\epsilon
$$

and in minimizing its loss function (distance to government's forecast) it has to disentangle the contribution of each of the three components of the error term: (i) $\epsilon$ is a technical error (model error); (ii) $\theta$ the political-bias-induced error; (iii) $\nu$ the error induced due to access to limited information. Thus, the independent agency faces a signal extraction problem.

\subsection{The role of sanctions}

Suppose that the EC may impose sanctions on the government depending on how far its fiscal forecasts are from the final outcome. In this case, it could influence the extent to which the government bases its forecast on $\Omega$ rather that $\Pi$. This can be done by imposing a penalty on the government if it deviates from a forecast based on the common information set, $\bar{x}_{\Omega}$. Let this penalty be forcing the government to choose a $\hat{x}$ given that there is a penalty $P$ given by $P=\beta\left(\hat{x}-\bar{x}_{\Omega}\right)$. Setting $\beta=0$ will lead the government to use $\Pi$ to minimize 
its own loss function, $\Lambda_{1}$, while setting $\beta=\infty$ will cause the government simply to report the common forecast $\bar{x}_{\Omega}$. More generally, the government would choose a $\hat{x}$ to minimize a weighted average of its own loss function $\Lambda_{2}$ and the additional penalty, $P$, with weight $\beta^{\prime}$, and given by $\beta^{\prime} \bar{x}_{\Omega}+\left(1-\beta^{\prime}\right)\left(\bar{x}_{\Pi}+\theta\right)$. In this case, a weight $\beta^{\prime}=\beta /(\beta+\gamma)$ ranges from 0 to 1 as $\beta$ ranges from 0 to $\infty$. The independent agency's loss function would be in this case:

$$
\begin{aligned}
L^{E C} & =E\left[x-\left\{\beta^{\prime} \bar{x}_{\Omega}+\left(1-\beta^{\prime}\right)\left(\bar{x}_{\Pi}+\theta\right)\right\} / \Omega\right]^{2} \\
& =E\left[x-\left\{\beta^{\prime}(x+\nu+\epsilon)+\left(1-\beta^{\prime}\right)(x+\epsilon+\theta)\right\} / \Omega\right]^{2}
\end{aligned}
$$

The EC would choose the value of the relative penalty, $\beta^{\prime}$ that minimizes its expected loss function. It is easy to find that such a value is:

$$
\beta^{\prime}=\frac{\sigma_{\theta}^{2}}{\sigma_{\nu}^{2}+\sigma_{\theta}^{2}}
$$

where $\sigma_{\nu}^{2}$ and $\sigma_{\theta}^{2}$ stand for the variance of the private information error and the politicallymotivated error, respectively. From this expression is clear that the EC has to force the government to use its superior information the larger $\sigma_{\nu}^{2}$, i.e. the greater the informational advantage is, and the smaller $\sigma_{\theta}^{2}$, i.e. the less unpredictable the political bias is.

\subsection{The signal extraction problem}

In general, the EC will try to minimize the distance to (biased) government projections. Its loss function would be of the kind: $L^{E C}=E\left[\left(x-\left\{\bar{x}_{\Pi}+\theta\right\}\right) / \Omega\right]^{2}$, which implies incurring in an error given by (4) $x-\bar{x}_{\Omega}=\nu+\theta+\epsilon$. Thus, in order to solve its signal extraction problem the EC has to form beliefs on $\theta, \nu$, and $\epsilon$.

If the EC runs a regression of $x-\bar{x}_{\Omega}$ on a constant, it knows that the constant would be a function of the errors, call it $\Phi(\theta, \nu, \epsilon)$. In order to isolate $\nu$ (good) from $\theta$ (bad) from $\epsilon$ (technical) it has to form a belief on the form of $\Phi(\theta, \nu, \epsilon)$. For example, $\Phi(\theta, \nu, \epsilon)$ can adopt the form of a linear projection on a constant and a function of some of the likely fundamentals of the political bias, like $\Phi(\theta, \nu, \epsilon) \approx c(\nu, \theta)+\Theta(s, E L E C)+\xi$. The constant $c$ would proxy the systematic part of the information bias, but also part of the political bias, ${ }^{13}$ while the

\footnotetext{
${ }^{13}$ It could also be the case that $\epsilon$ had non-zero mean, associated to non-optimal forecasts' production processes and the use of non-optimal forecasting methods, in which case the constant would also partially reflect this.
} 
function $\Theta(s, E L E C)$ would proxy the part of the political bias determined by fundamentals, where $s$ is a variable linked to the state of the business cycle and $E L E C$ a variable that captures the electoral cycle, and $\xi$ a normally distributed zero-mean random disturbance term. From the empirical point of view the EC can run a standard linear regression on the series of its forecast errors (as it is customary in the literature)

$$
x-\bar{x}_{\Omega}=\delta_{0}+\delta_{1} E L E C+\delta_{2} G D P+\xi
$$

were time subindexes have been dropped for simplicity and GDP stands for real GDP forecast errors by the EC. Then it will get estimates of the coefficients in the regression: $\hat{\delta}_{0}$, $\hat{\delta}_{1}$ and $\hat{\delta}_{3}$. Even if the constant, $\hat{\delta}_{0}$, can be partly interpreted as reflecting the lack-of-accessto-the-private-information-bias, in will also reflect part of the political bias if we assume that the EC is minimizing the distance to government's projections; if EC forecasts were produced independently, the constant would just capture the first factor. Now, it is feasible within our framework that $\hat{\delta}_{1}$ turns out to be statistically different from zero, given that it would capture also part of the "inherited" political bias. In fact, even though $\hat{\delta}_{2}$ should capture the genuine impact of errors in forecasting GDP on fiscal forecast errors (most notably in revenue estimation), it could also be the case that it is affected by political biases, to the extent that political cycles are linked to the state of the business cycle.

A regression on government's projection errors of the type of (5) would produce a set of coefficients, $\hat{\delta}_{0}^{G O V}, \hat{\delta}_{1}^{G O V}$ and $\hat{\delta}_{2}^{G O V}$, that can be compared with $\hat{\delta}_{0}, \hat{\delta}_{1}$ and $\hat{\delta}_{2}$. The difference of constant terms $\hat{\delta}_{0}-\hat{\delta}_{0}^{G O V}$ would be difficult to interpret, as it will mix-up all the sources of bias discussed above, even though the coefficient for the government has a clean interpretation as political bias. As regards $\hat{\delta}_{1}-\hat{\delta}_{1}^{G O V}$, one might expect it to be negative. Finally, as to $\hat{\delta}_{2}-\hat{\delta}_{2}^{G O V}$, an expected sign would be positive as government projections should be less sensitive to changes in macro fundamental and be more judgemental, reflecting the impact of $s$ discussed above.

The theoretical discussion in this Section has implications for the empirical part that follows, in particular in the interpretation of the results. We turn now to the empirical part of the paper, starting with the description of the real-time database and the variables included in the empirical analysis. 


\section{Data description}

\subsection{The real-time database of fiscal forecast errors}

Let us denote by $d_{t+1}$ the government deficit observed in year $t+1$. International agencies typically prepare forecasts for $d_{t+1}$ from different forecast origins at different moments in time. In particular, we will focus on the sequence of projections of $d_{t+1}$ that starts with a projection prepared with information up to Spring of year $t$ (Spring one-year-ahead forecast), and then it is updated in Autumn of year $t$ (Autumn one-year-ahead forecast), and further in year $t+1$ in Spring (Spring current-year forecast) and Autumn (Autumn current-year forecast). Notice that the four described forecasts for $d_{t+1}$ differ in the information set available at the time of preparation of the projection. Let us define Spring one-year-ahead forecasts, Autumn one-year-ahead forecasts, Spring current-year forecasts and Autumn current-year forecasts as, $E_{t}\left[d_{t+1} / S_{t}\right], E_{t}\left[d_{t+1} / A_{t}\right], E_{t+1}\left[d_{t+1} / S_{t+1}\right]$ and $E_{t+1}\left[d_{t+1} / A_{t+1}\right]$ respectively. Then one can define the following forecast errors:

$$
\begin{aligned}
\epsilon_{t+1}^{S_{t}} & \equiv d_{t+1}-E_{t}\left[d_{t+1} / S_{t}\right] \\
\epsilon_{t+1}^{A_{t}} & \equiv d_{t+1}-E_{t}\left[d_{t+1} / A_{t}\right] \\
\epsilon_{t+1}^{S_{t+1}} & \equiv d_{t+1}-E_{t+1}\left[d_{t+1} / S_{t+1}\right] \\
\epsilon_{t+1}^{A_{t+1}} & \equiv d_{t+1}-E_{t+1}\left[d_{t+1} / A_{t+1}\right]
\end{aligned}
$$

The vintage structure of the database is explained further in Figure 1. The analysis by vintages allows us to classify the literature most directly related to our work, that is described in Table 1. There we list the main papers dealing with public deficit's forecast errors in Europe. Some papers focus on the analysis of $E_{t}\left[d_{t+1} / A_{t}\right]$, while others look at projections prepared in Spring of year $t$ for year $t, E_{t}\left[d_{t} / S_{t}\right]$. These papers try to explain public deficit forecast errors (or just forecasts) by means of explanatory variables labeled as economic (like actual/forecast GDP growth or the output gap) and political/institutional (like election year or fiscal governance structure). The other papers in the table analyze projections for European government's public deficits as prepared by international organizations, most notably the EC. Keereman (1999), Artis and Marcellino (2001) and Melander et al. (2007) look at the properties of the whole vintage of forecasts errors $\left(E_{t}\left[d_{t+1} / S_{t}\right], E_{t}\left[d_{t+1} / A_{t}\right]\right.$, 
$E_{t+1}\left[d_{t+1} / S_{t+1}\right]$ and $\left.E_{t+1}\left[d_{t+1} / A_{t+1}\right]\right)$ but following a purely descriptive approach (size and sign of errors, presence of biases, rationality).

As stated in the introduction, two main shortcomings emerge from this literature: (i) there are no studies that compare the accuracy of the fiscal forecasts prepared by the governments and those prepared by other institutions (either international or private); (ii) most papers focus on one single vintage of forecasts. To deal with these shortcomings, we build up a real-time database of forecasts for the public deficit and GDP, as published by the EC, the OECD and European governments. In particular, EC projections have been taken from the different issues of the publication European Economy (Supplement A, Economic Trends). For the OECD, the source is the OECD Economic Outlook. Both the EC and the OECD publish projections for the current year and one-year ahead twice a year, in Spring and Autumn. As regards governments' projections, the data have been compiled from two sources. On the one hand, current year projections have been taken from the EDP Notifications, submitted twice a year (in Spring and Autumn) by European governments to the European Commission in the framework of the so-called Excessive Deficit Procedure. On the other hand, Autumn, one-year-ahead projections have been taken from the Stability and Convergence Programmes, submitted at the end of each year by European governments to the European Commission. ${ }^{14}$ No figures are available for the Spring one-year-ahead vintage.

The time period covered by our database is 1999-2007, and includes the 15 countries members of the EU prior to the 2004 EU enlargement, namely Belgium, Germany, Greece, Ireland, Spain, France, Italy, Luxembourg, Netherlands, Austria, Portugal, Finland, Denmark, Sweden, and the United Kingdom. All in all, taking into account certain missing figures, the number of available observations for the four consecutive vintages $\left(E_{t}\left[d_{t+1} / S_{t}\right], E_{t}\left[d_{t+1} / A_{t}\right]\right.$, $\left.E_{t+1}\left[d_{t+1} / S_{t+1}\right], E_{t+1}\left[d_{t+1} / A_{t+1}\right]\right)$ is respectively $(0,120,128,135)$ for government's projections, $(120,120,135,135)$ for EC projections and $(117,118,132,133)$ for OECD projections. ${ }^{15}$

\footnotetext{
${ }^{14} \mathrm{EU}$ countries send updated fiscal projections to the European Commission at least three time a year. Firstly, at the end of a given year (November/December) or the beginning of the next year (January) national fiscal authorities submit to the EC Stability and Convergence Programmes. These Programmes include multi-annual fiscal projections covering three to four years ahead. Secondly, national governments send to the EC in Spring of each year t the initial release of data for year $t-1$, and also take the opportunity to report updated projections for year t. Finally, the latter release of past data and estimates for the current year is updated in Autumn of each year.

${ }^{15}$ All over the study forecasts are lined up with the year in which the forecast was made, not the year
} 
As an example of the reflection of the vintage structure in the data, Figure 2 shows the distribution of government public deficit forecast errors computed from EC projections, for the pool made of the 15 analyzed countries. It displays four projections for year $\mathrm{t}$ deficit, that differ in the selected forecast origin, the first one being the projection prepared in spring of $\mathrm{t}$ for year $\mathrm{t}+1\left(E_{t}\left[d_{t+1} / S_{t}\right]\right)$. The figure presents the statistical distribution of projections errors and its evolution by vintage. The distribution of projection errors appears to be slightly twisted to under-prediction of budget balances, which might be evidence for the presence of bias in the pool. This seems to be particularly true for current year autumn projections. In addition, there seems to be some evidence for increased accuracy across consecutive vintages.

Table 2 shows some descriptive statistics of the real-time data set. Mean errors over the whole sample were positive for GOV, EC and OECD projections, thus presenting a small pessimistic positive bias (under-prediction of budget balances) over the years 1999 to 2007. Nevertheless, when accounting for variability, only the Autumn current year vintage turned out to be statistically significant from zero in the case of the three institutions. The optimistic bias was higher in size and statistically significant for the last three vintages in the case of the EC and in the current-year vintages in the case of the OECD. Given that the sample includes two upswing periods but only one downswing, this can be an indication of a more prudent approach to public deficit projections on the side of international agencies.

Turning to the Mean Absolute Error and the RMSE statistics, also presented in Table 2, two facts can be highlighted. First, accuracy improves with the information set, as expected, given that both statistics get reduced as the information set gets closer to Autumn of the current year. Second, the size of forecast errors by the EC and OECD is commensurate or lower than that of governments when looking at Autumn one-year-ahead forecasts and Spring current-year ones; the estimates at the end of the current year (Autumn current-year forecast), though, improve significantly in the case of GOV when compared with EC and OECD estimates. This latter fact may reflect again the conservative bias on the side of international agencies mentioned before, but also the existence of private information on the side of GOV, most likely on budgetary execution (and in particular as regards expenditures). being forecast. 


\subsection{Other variables}

Along with the real-time database of government deficit forecasts, we also compile a parallel real-time database of real GDP forecasts for the same organizations and taken from the same publications in each case as with the deficit projections. Errors committed when forecasting macroeconomic variables are responsible for an important part of fiscal forecast errors (see for example Leal et al. 2008) and thus it is natural to include a proxy for this (GDP errors) in the analysis. For example, optimistic revenue forecasts tend to be associated to optimistic GDP forecasts (Jonung and Larch 2006).

As with political budget cycles (Andrikopoulos et al., 2004, Economides et al., 2003, Sapir and Sekkat, 2002), there may be electoral, partisan or institutional forecast cycles. In the case of political forecast cycles, policy makers deceive the public and the EC on their true budgetary position in order to exploit the Phillips curve in the short-run. In an electoral forecast cycle, a given election date determines government's spending and taxation plans and the corresponding information policy (Alesina et al., 1998, Darby et al., 2004, Frey and Scheneider, 1975, Nordhaus, 1975, Rogoff, 1990, Rogoff and Sibert, 1988). For example, a government may increase spending prior to an election and hide the emerging budget deficit, exploiting temporary information asymmetries. We capture these effects by including country dummy variables that display a value of 1 in an election year and a zero otherwise. We took the data from Armingeon et al. (2008) for the period 1999-2005, and extended the variables by ourselves for 2006 and 2007 .

During the time period chosen for our analysis (1999-2007) the fiscal framework was basically the same for all countries, the SGP (and its reformed version in place since 2005). Political institutions changed also very little in the period 1999-2007 in the 15 EU countries considered. Thus, after some initial tests, we decided to let the fixed effects of the models capture differences in institutions across countries.

\section{Empirical strategy and results}

\subsection{Empirical strategy}

As posed in the Introduction, we are interested in testing the following hypotheses: 
$H_{1}$ : Is the forecast performance of governments as regards budgetary projections worse than that of international organizations (like the EC and the OECD)?

$H_{2}$ : Is there robust evidence of political economy distortions in fiscal projections prepared by international organizations?

Quite importantly, to answer these questions we use a common methodology, i.e. the same econometric method and the same empirical specification, to look at all the alternative datasets (by institution, by vintage), over the same sample period.

The baseline equation we estimate is as follows:

$$
\epsilon_{t, I}^{D E F}=\delta_{0, I}+\delta_{1, I} E L E C_{t, i}+\delta_{2, I}^{h} \epsilon_{t, I}^{G D P}+\delta_{3, I} D_{t, I}^{G O V}+\sum_{p=4}^{P}\left\{\delta_{p, I} D_{t}^{p}\right\}+\xi_{t, I}
$$

where $\epsilon_{t, I}^{D E F}$ is defined as in (6). $I=\{i, j, h\}$ represents in a compact form the three relevant sub-indexes country, institution and vintage of projection. $i$ is the country index; $j$ the institution index, $j=(G O V, E C, O E C D) ; E L E C$ is a dummy for electoral periods, that is composed of 0's (no election in year t in country $i$ ) and 1's (every time year t is an election year in country $i) ; \epsilon^{G D P}$ do refer to errors in forecasting real GDP of country $i$ in year $t$ incurred by institution $j$ at vintage $h ; D^{G O V}$ is a dummy for government forecasts, that takes the value of 1 if $j=G O V ; h$ refers to the vintage of projections $h=\left\{S_{t}, A_{t}, S_{t+1}, A_{t+1}\right\} . D_{t}^{p}$ represents additional dummy variables needed in the analysis, that will be detailed in the course of the analysis.

Country-level fixed effects are also included in all regressions and control for differences in budgetary procedures among countries. We leave the constant the job of accounting for differences in institutional determinants given, first, our cross-organizations approach and, second, the fact that in the analyzed sample only a few country-specific institutional changes did occur. In the latter respect, von Hagen (2010) analyzes the influence of fiscal institutions on budgetary deviations from governments' plans over the period 1999-2004 and decides to leave out country fixed-effects throughout his empirical study. The justification for this is that country fixed-effects would absorb, if introduced, the effect of institutional dummies as institutions did not changed over the sample period. 
To correct for groupwise heteroskedasticity of error variances and cluster cross-correlation, all regressions use estimators with cross-sectional, panel-corrected standard errors. Given also that $G D P_{t, j, i}$ might likely be endogenous and thus correlated with the error term of the regression, we decided to use a two-stages instrumental variable method (IV) henceforth. ${ }^{16}$ Given the characteristics of our dataset, controlling carefully for cross-correlation is crucial. This is the case because in some regressions we include forecasts of different institutions for the same country, and/or forecasts prepared by the same institution for different vintages. Thus due account of clustering is implemented. As regards heteroskedasticity, some countries/institutions may display more volatile deficit forecasts and more/less accuracy.

\subsection{Empirical results}

We show a first set of results for the pool of all countries, all institutions and all vintages. These results are presented in Table 3 and constitute the most important set of results in the paper. Column [1] of the table presents the results for the most comprehensive pool. There, the dummy for the government does not show up significant; within the pool, the information available cannot distinguish forecast errors by governments from those by the two international organizations in the sample. GDP errors are significant and the average estimated point elasticity is 0.48 , along the lines of related studies; the positive sign says that a negative GDP growth shock produces ex-post optimistic government revenue and deficit forecasts. The dummy for elections years is significantly different from zero and negative: it contributed to optimistic deficit forecasts; on average over all the dimensions considered, projected deficits underestimated by $0.44 \%$ of GDP actual public deficits. The regression also included two additional, control dummies. On the one hand, the dummy for countries subject to and EDP procedure ${ }^{17}$ is negative and significant, indicating that on average EDP countries prepared more optimistic deficit forecasts than non-EDP countries.

\footnotetext{
${ }^{16}$ Regressions are run using the ivreg2 command in STATA version 11. Using Weighted Least Squares provided similar results to those obtained by IV in some cases, and are thus presented in some tables for comparability with related studies.

${ }^{17}$ I.e. those countries within the sample that have been subject to an Excessive Deficit Procedure, i.e. countries that have exceeded the 3\% of GDP public deficit dictated by EU fiscal rules at any time $t$ within the sample 1999-2007. These countries are Germany, France, United Kingdom, Greece, Italy, Netherlands and Portugal. These countries might exhibit a differentiated behavior within the analyzed sample as they have been less disciplined while at the same time subject to peer pressure by the other EU countries and the EC.
} 
On the other hand, the good-times dummy turned out to be positive and significant, showing that countries tend to be on average more pessimistic when the economic situation is buoyant than otherwise. Finally, it is worth mentioning that leaving out fixed-effects and the EDP dummy unveils a significant and negative constant, that makes explicit the presence of an average optimistic bias in deficit projections. Column [2] breaks down the impact of the election dummy by institutions. Standard tests show that the coefficient of the interaction term "elections $\times$ GOV" is significantly higher than the ones corresponding to the EC and the OECD. This can be interpreted as a sign of more independent fiscal forecasts by international organizations. Overall, WLS estimations shown in columns [7] and [8] display similar qualitative results to those obtained by IV in columns [1] and [2].

Still in Table 3, columns [3] to [6] present the same analysis as before but split into good times and bad times. In bad times the peer and EU-wide institutional pressure might be stronger and thus $\theta$ might be smaller than in good times, and also its variance $\sigma_{\theta}^{2}$ might be smaller. On different grounds, in good times it might be easier for international organizations to get governments to disclose their private information, so that $E(\nu)$ should be smaller than in bad times and thus international organizations might find easier to differentiate their forecasts from those of the governments. On the contrary, in bad times governments may have more incentives to use it in a confidential way and thus EC and OECD projections should be more difficult to be differentiated from those of the governments. In bad times, thus, it should be more difficult to disentangle $\theta$ from $\nu$, and then EC and OECD forecasts would tend to be closer to government's ones. These intuitions are confirmed by the empirical analysis. In this respect, the most salient features of the empirical estimations are, in this case, the following. First, fiscal forecasts turned out to be more judgemental, i.e. less responsive to GDP errors, in bad times than in good times. This is consistent with the usual approach to conduct discretionary policies more actively in times of distress, typically by implementing expansionary measures at the beginning of a downturn and implementing fiscal adjustment measures when public debt build-ups beyond certain, sustainable limits. Second, governments display a distinct optimistic deficit bias in good times (the "dummy government" is negative and significant), while in bad times they seem to be more line with the other institutions. Third, bad times exert a kind of discipline over EDP countries, as the 
relevant dummy is not significant in those periods. Fourth, the negative influence of electoral cycles, even though being significant in both types of periods, is more muted in bad times than in good times, and only in the latter periods are international organizations clearly different from governments in this respect. Finally, with all the caveats in interpretation, the constant term (when fixed-effects and EDP dummies are excluded from the regressions) is negative in bad times (optimistic bias) and positive in good times (conservative bias).

Table 4, in turn, disaggregate the information presented above by vintage of projections. Some interesting insights can be highlighted: (i) the importance of errors in GDP as a explanatory factor of public deficit errors decreases, in general, with the vintage, i.e. the closer the projection to the forecast year, revealing an increased GDP accuracy as the information set gets increased, but also more weight on pure fiscal factors vs macro fundamentals in the forecast process (like for example short-term data on budgetary execution); nevertheless, the Spring current-year vintage is the one with the least weight on GDP errors, because it benefits less from the first factor and at that point of the year still not enough from the second; (ii) the dummy for electoral dates is negative for all vintages but it is only significant for the vintages with forecast origin within the year of the election; (iii) in the case of the Spring current year vintage the dummy for government projections turns out to be significant, showing an optimistic bias in Spring-current-year projections, that vanishes for Autumn-current-year projections, the time of budget preparation; it is worth noticing that it is in current year vintages in which the availability of private information is more relevant, in particular as regards data on budgetary execution by sub-national governments; (iv) the fixed effects country dummies (and the constant from the regression without fixed effects) display a conservative bias for farther-from-the-forecast-origin vintages the forecast year, with the size of the bias decreasing monotonically with the vintage. Overall, the Spring current year vintage seems to be the one more judgemental and subject to political biases, and this is precisely the vintage of projections published at the time of the year that is most relevant from the point of view of implementing corrective fiscal measures in order to guarantee that budgetary targets are met. 


\section{Conclusions}

We provide empirical evidence on the existence of political economy determinants of international organizations' (EC and OECD) fiscal forecasts for EU countries over the period 1999-2007. This evidence is based on a broad real-time database over a homogeneous time period. We confirm and expand previous evidence pointing to the fact that international agencies' track record of fiscal forecasts do present bias and correlation with electoral cycles in EU countries. We frame the empirical analysis by means of a model in which an independent agency tries to minimize the distance to government's forecast, given that that government's information set includes private information not available to the independent agency. When preparing their fiscal projections, independent agency's staff tries to grasp as much private information as possible from the government, while at the same time have to disentangle "political biases" from genuine "private information". Thus, the presence of an inherited bias in international agencies' fiscal forecasts stems naturally in this set up.

The analysis and results of this paper do have important implications for the current policy debate, specially in Europe. Institutional changes have to be implemented in the procedures of elaboration of fiscal projections by international organizations if they are to qualify as agencies in charge of the preparation of fiscal forecasts that could frame or tie government's fiscal forecasts, as international agencies' fiscal forecasts have not been better in the past than governmental ones. Possible institutional improvements include, on the one hand, those aiming at improving transparency on fiscal data reporting (to minimize ex-ante the "private information bias" $\nu$ ) and accountability (to minimize ex-ante the "political bias" $\theta$ ) and, on the other hand, those increasing ex-ante pressure on misbehaving governments, like the imposition of sanctions, given that a penalty on government's fiscal forecast errors may be helpful to minimize the "private information" bias in government's forecasts.

\section{References}

Aldenhoff, F. O. (2007), "Are economic forecasts of the International Monetary Fund politically biased? A public choice analysis", Review of International Organizations, 2, 239-260. 
Annett, A. (2006), "Enforcement and the Stability and Growth Pact: How Fiscal Policy Did and Did Not Change Under Europe's Fiscal Framework", IMF Working Paper $2006 / 116$.

Arellano, M. and Bond, S. (1991), "Some tests of specification of panel data: Monte Carlo evidence and an application to employment equations", Review of Economic Studies, $58,277-297$.

Armingeon, K., Gerber, M., Leimgruber, P., Beyeler, M. and Menegale, S. (2008), "Codebook: Comparative political data set I, 1960-2005”. Institute of Political Science, University of Berne.

Artis, M. and Marcellino, M. (2001), "Fiscal forecasting: the track record of the IMF, teh OECD and the EC", The Econometrics Journal, 4, S20-S36.

Artis, M. and Marcellino, M. (1998), "Fiscal solvency and fiscal forecasting in Europe", Centre for Economic Policy Research (CEPR), Discussion Paper no. 1836.

Auerbach, A.J. (1999), "On the Performance and Use of Government Revenue Forecasts", National Tax Journal, 52, 765-782.

Auerbach, A.J. (1996), "Dynamic Revenue Estimation", Journal of Economic Perspectives, $10,141-157$.

Auerbach, A. J. (1995), "Tax projections and the budget: lessons from the 1980s", American Economic Review, 85, 1659.

Baguestani, H. and McNown, R. (1992), "Forecasting the federal budget with time series models", Journal of Forecasting, 11, 12739.

Batchelor, R. (2001), "How useful are the forecasts of intergovernmental agencies? The IMF and OECD versus the consensus", Applied Economics, 33, 225-235.

Beetsma, R., B. Bluhm, M. Giuliodori and P. Wierts (2012), "From budgetary forecasts to ex-post fiscal data: exploring the evolution of fiscal forecast errors in the EU", Contemporary Economic Policy, forthcoming. 
Beetsma, R., M. Giuliodori and P. Wierts (2009), "Planning to Cheat: EU Fiscal Policy in Real Time", Economic Policy, 24, 753-804.

Bischoff, I. and Gohout, W. (2010), "The political economy of tax projections", International Tax and Public Finance, 17, 133-150.

Blix, M., Wadefjord, J., Wienecke, U. and Ådahl, M. (2001), "How good is the forecasting performance of major institutions", Economic Review No 3, Sveriges Risksbank.

Boylan, R. T. (2008), "Political distortions in state forecasts", Public Choice, 136, 41127.

Bretschneider, S.I., Gorr, W.L., Grizzle, G., and Klay, E. (1989), "Political and organizational influences on the accuracy of forecasting state government revenues", International Journal of Forecasting, 5, 307-319.

Brück, T., Stephan A. (2006), "Do Eurozone Countries Cheat with their Budget Deficit Forecasts", Kyklos, 59, 3-15.

Cassidy, G., Kamlet, M. S., and Nagin, D. S. (1989), "An empirical examination of bias in revenue forecasts by state governments", International Journal of Forecasting, 5, $321-331$.

Christodoulakis, G. A. and E. C. Mamatzakis (2009), "Assessing the prudence of economic forecasts in the EU", Journal of Applied Econometrics, 24, 583-606.

Cohen, D. and Follete, G. (2002), "Forecasting government taxes and spending in the United States: an overview", paper presented at the 1st centrA Workshop on Public Sector Forecasting and Monitoring, Seville, 2728 September.

Debrun, X., Hauner, D. and Kumar, M. S. (2009), "Independent fiscal agencies", Journal of Economic Surveys, 23, 44-81.

Dreher, A., Marchesi, S., Vreeland, J. R. (2008), "The political economy of IMF forecasts", Public Choice, 137, 145-171. 
European Commission (2006), "Part III: National numerical fiscal rules and institutions for sound public finances", pp. 135-195 in "Public finances in EMU", European Economy, No 3.

Feenberg, D.R., Gentry, W., Gilroy, D., and Rosen, H.S. (1989), "Testing the rationality of State Revenue Forecasts", Review of Economics and Statistics, 71, 300-308.

Frankel, J. A. (2011), "Over-optimism in forecasts by official budget agencies and its implications", NBER Working Papers 17239, July.

Fullerton, T. M., Jr (1989), "A composite approach to forecasting state government revenues: case study of the Idaho sales tax", International Journal of Forecasting, 5, 37380.

Gentry, W.M. (1989), "Do State Revenue Forecasters Utilize Available Information?", National Tax Journal, 42, 429-39.

Hallerberg, M., Strauch, R. and von Hagen, J. (2007), "The design of fiscal rules and forms of governance in European Union countries", European Journal of Political Economy, 23, 338-359.

Holden, K., and Peel, D. A. (1990), "On testing for unbiasedness and efficiency of forecasts", The Manchester School, 63, 120-127.

Jennes, B. and Arabackyj, S. (1998), "Budget forecasting records of the federal and provincial governments", Monthly Economic Review, Canada, 17, no. 1.

Jonung, L., and Larch, M. (2006), "Fiscal policy in the EU: are official output forecasts biased?", Economic Policy, July, 491-534.

Keereman, F. (1999), "The track record of Commission Forecasts", European Commission Economic Papers, n. 137.

Leal, T., Pérez, J. J., Tujula, M. and Vidal, J.-P. (2008) "Fiscal forecasting: lessons from the literature and challenges", Fiscal Studies, 29, 347-386. 
Marinheiro, C. F. (2010), "Fiscal sustainability and the accuracy of macroeconomic forecasts: do supranational forecasts rather than government forecasts make a difference?", GEMF Working Papers 2010, 7, Faculty of Economics, University of Coimbra.

Melander, A., Sismanidis, G. and Grenouilleau, D. (2007), "The track record of the Commission's forecasts - an update", European Economy Economic Papers, No 291, October.

Melliss, C. (1997), "The Treasury forecast record: an evaluation", ESRC Macroeconomic Modelling Bureau, Discussion Paper no. 47.

Melliss, C. and and Whittaker, R. (1998), "The Treasury forecast record: some new results", National Institute Economic Review, April, pp. 6579.

Mocan, H. N., and Azad, S. (1995), "Accuracy and Rationality of State General Fund Revenue Forecasts: Evidence from Panel data", International Journal of Forecasting, $1,417-427$.

Moulin, L., and Wierts, P. (2006), "How Credible are Multiannual Budgetary Plans in the EU?", in Fiscal Indicators, pp. 983-1005, Banca d'Italia.

Mhleisen, M., Danninger, S., Hauner, D., Krajnyck, K. and Sutton, B. (2005), "How do Canadian budget forecasts compare with those of other industrial countries?", International Monetary Fund, Working Paper no. WP/05/66.

Pina, A. and N. Venes (2011), "The political economy of EDP fiscal forecasts: an empirical assessment", European Journal of Political Economy, 27, 534-546.

Plesko, G.A. (1988), "The accuracy of government forecasts and budget projections", National Tax Journal, 41, 483-501.

Pons, J. (2000), "The accuracy of IMF and OECD forecasts for G-7 countries", Journal of Forecasting, 19, 53-63.

Poplawski-Ribeiro, M. and Rülke, J.-C. (2010), "Fiscal expectations and the Stability and Growth Pact: evidence from survey data", CEPII Working Paper No 2010-05, March. 
Roodman, D. (2005), "xtabond2: Stata module to extend xtbond dynamic panel estimator", Center for Global Development, Washington D.C.

Shkurti, W.J., and Winefordner, D. (1989), "The politics of state revenue forecasting in Ohio, 1984-1987: A case study and research implications", International Journal of Forecasting, 5, 361-371.

Strauch, R., Hallerberg, M., von Hagen, J. (2004), "Budgetary Forecasts in Europe - The Track Record of Stability and Covergence Programmes", European Central Bank WP 307.

Timmermann, A. (2007), "An evaluation of the World Economic Outlook forecasts", IMF Staff Papers, 54, 1-33.

von Hagen, J. (2010), "Sticking to fiscal plans: the role of institutions", Public Choice, 144, 487-503.

von Hagen, J. and I. H. Harden (1994), "National budget processes and fiscal performance", European Economy Reports and Studies, 3, 311-418.

Windmeijer, F. (2005), "A finite sample correction for the variance of linear efficient twostep GMM estimators", Journal of Econometrics, 126, 25-51.

Wyplosz, C. (2008), "Fiscal policy councils: Unlovable or just unloved", Swedish Economic Policy Review, 15, 173-192. 
Figure 1: Structure of the database: Spring and Autumn vintages, current year and oneyear-ahead forecasts.

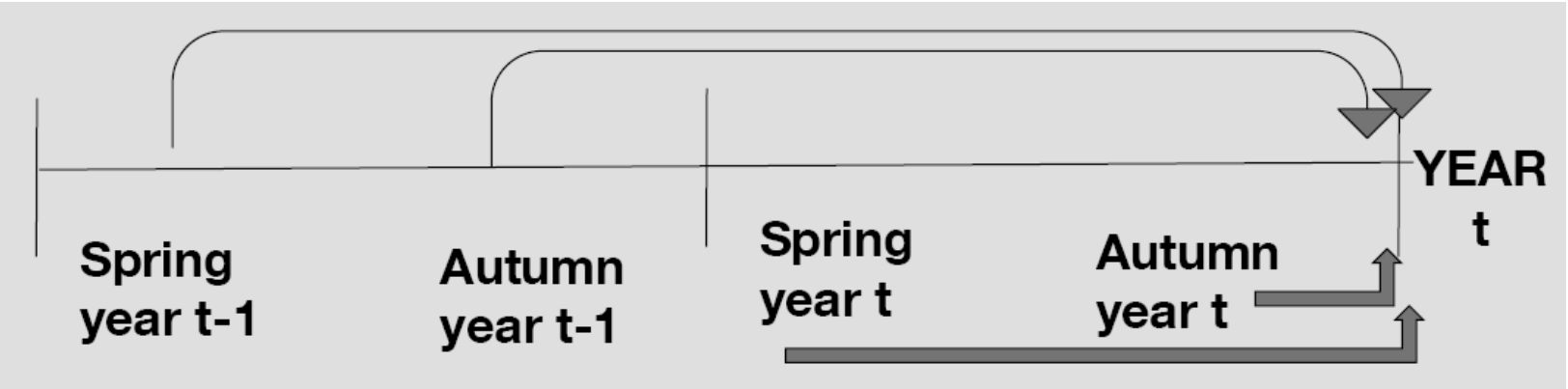


Figure 2: Distribution of budget balance projection errors, \% of GDP. EC projections, 19992006 .
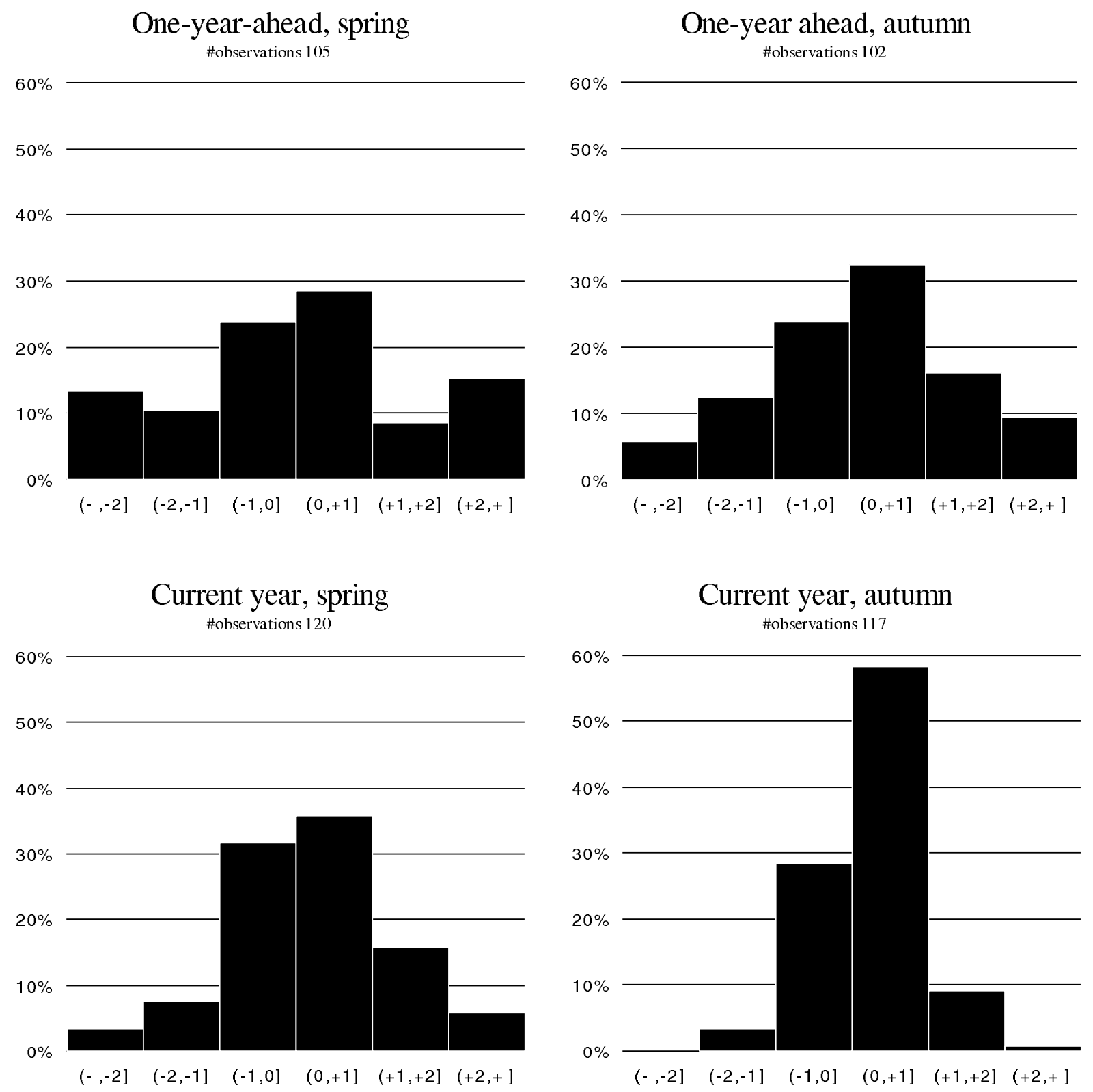
Table 1: Some related literature analyzing public deficit forecast errors in EU countries.

\begin{tabular}{|c|c|c|c|c|c|}
\hline \multirow{2}{*}{$\begin{array}{l}\text { Main papers and } \\
\text { time periods covered }\end{array}$} & \multirow{2}{*}{$\begin{array}{l}\text { Information } \\
\text { source }\end{array}$} & \multirow{2}{*}{$\begin{array}{l}\text { Type of } \\
\text { analysis }\end{array}$} & \multicolumn{3}{|c|}{ Forecasts of organization: } \\
\hline & & & $\mathrm{EC}$ & OECD & Governments \\
\hline $\begin{array}{l}\text { Strauch et al. (2004) } \\
1991-2002\end{array}$ & National $^{a}$ & Econometric & - & - & $\begin{array}{c}E_{t}\left[d_{t+j} / A_{t}\right] \\
j=0,1,2\end{array}$ \\
\hline $\begin{array}{l}\text { Brück \& Stephan (2006) } \\
\text { 1995-2003 }\end{array}$ & $\mathrm{EC}^{b}$ & Econometric & - & - & $\begin{array}{c}E_{t}\left[d_{t+j} / A_{t}\right] \\
j=1\end{array}$ \\
\hline $\begin{array}{l}\text { von Hagen (2010) } \\
\text { 1999-2004 }\end{array}$ & National $^{a}$ & Econometric & - & - & $\begin{array}{c}E_{t}\left[d_{t+j} / A_{t}\right] \\
\quad j=0,1,2\end{array}$ \\
\hline $\begin{array}{l}\text { Pina \& Venes (2011) } \\
1994-2006\end{array}$ & $\begin{array}{l}\text { National } \\
\operatorname{EDP} c\end{array}$ & Econometric & - & - & $\begin{array}{l}E_{t}\left[d_{t} / S_{t}\right] \\
E_{t}\left[d_{t} / A_{t}\right]\end{array}$ \\
\hline $\begin{array}{l}\text { Annet }(2006) \\
1980-2004\end{array}$ & National $^{a}$ & Econometric & - & - & $E_{t}\left[d_{t+1} / A_{t}\right]$ \\
\hline $\begin{array}{l}\text { Moulin \& Wierts (2006) } \\
\text { 1998-2005 }\end{array}$ & National $^{a}$ & Econometric & - & - & $E_{t}\left[d_{t+1} / A_{t}\right]$ \\
\hline $\begin{array}{l}\text { Beetsma et al. (2012) } \\
\text { 1998-2008 }\end{array}$ & National $^{a}$ & Econometric & - & - & $\begin{array}{c}E_{t}\left[d_{t+j} / A_{t}\right] \\
j=0,1,2\end{array}$ \\
\hline $\begin{array}{l}\text { Artis \& Marcellino (2001) } \\
1975-1995^{e}\end{array}$ & $\begin{array}{l}\mathrm{EC}^{b} \\
\mathrm{OECD}^{d}\end{array}$ & Descriptive & $\begin{array}{c}\text { All } \\
\text { vintages }\end{array}$ & $\begin{array}{c}\text { All } \\
\text { vintages }\end{array}$ & - \\
\hline $\begin{array}{l}\text { Keereman (1999) } \\
\text { 1970-1997 }\end{array}$ & $\mathrm{EC}^{b}$ & Descriptive & $\begin{array}{c}\text { All } \\
\text { vintages }\end{array}$ & - & - \\
\hline $\begin{array}{l}\text { Melander et al. (2007) } \\
\text { 1970-2005 }\end{array}$ & $\mathrm{EC}^{b}$ & Descriptive & $\begin{array}{c}\text { All } \\
\text { vintages }\end{array}$ & - & - \\
\hline $\begin{array}{l}\text { Marinheiro (2010) } \\
\text { 1999-2007 }\end{array}$ & $\mathrm{EC}^{b}$ & Descriptive & $\begin{array}{c}\text { All } \\
\text { vintages }\end{array}$ & - & - \\
\hline
\end{tabular}

Notes: ${ }^{a}$ National sources: Stability and Convergence Programmes by EU Member States.

${ }^{b}$ European Commission, several vintages of the publication "European Economy- Economic Forecasts".

${ }^{c}$ EDP reports: Excessive Deficit Procedure reports.

${ }^{d}$ OECD Economic Outlook.

$e$ Their analysis also covers IMF projections (World Economic Outlook).

$f$ "Descriptive" refers to the implementation of standard measures of forecast accuracy, including directional accuracy, plus traditional bias and efficiency tests. "Econometric" do refer to the inclusion of economic, political and/or institutional variables as explanatory variables of public deficit's forecast errors. 
Table 2: Some descriptive statistics of the sample of government deficits' forecast errors.

\begin{tabular}{c|ccc|ccc|ccc} 
& \multicolumn{3}{|c|}{$\begin{array}{c}\text { Mean Error } \\
\text { Statistic }\end{array}$} & $\begin{array}{c}\text { Mean Absolute Error } \\
\text { Statistic }\end{array}$ & \multicolumn{3}{c}{$\begin{array}{c}\text { Root Mean Squared } \\
\text { Error Statistic }\end{array}$} \\
& GOV & EC & OECD & GOV & EC & OECD & GOV & EC & OECD \\
\hline$\epsilon_{t+1}^{S_{t}}$ & - & 0.20 & 0.12 & - & 1.30 & 1.30 & - & 1.70 & 1.71 \\
$\epsilon_{t+1}^{A_{t}}$ & 0.13 & $0.28^{b}$ & 0.19 & 1.03 & 1.02 & 1.06 & 1.40 & 1.32 & 1.43 \\
$\epsilon_{t+1}^{S_{t+1}}$ & 0.16 & $0.29^{a}$ & $0.25^{a}$ & 0.91 & 0.79 & 0.79 & 1.25 & 1.06 & 1.06 \\
$\epsilon_{t+1}^{A_{t+1}}$ & $0.23^{a}$ & $0.25^{a}$ & $0.20^{a}$ & 0.44 & 0.49 & 0.52 & 0.67 & 0.68 & 0.74 \\
\hline \hline
\end{tabular}

Notes: ${ }^{a}$ Significant at $1 \%{ }^{b}$ Significant at $5 \% ;{ }^{c}$ Significant at $10 \%$.

$\epsilon_{t+1}^{S_{t}} \equiv d_{t+1}-E_{t}\left[d_{t+1} / S_{t}\right]$ are Spring one-year-ahead forecast errors; $\epsilon_{t+1}^{A_{t}} \equiv d_{t+1}-E_{t}\left[d_{t+1} / A_{t}\right]$ are Autumn one-year-ahead forecast errors; $\epsilon_{t+1}^{S_{t+1}} \equiv d_{t+1}-E_{t}\left[d_{t+1} / S_{t+1}\right]$ are Spring current-year forecast errors; $\epsilon_{t+1}^{A_{t+1}} \equiv d_{t+1}-E_{t}\left[d_{t+1} / A_{t+1}\right]$ are Autumn current-year forecast errors. 
Table 3: Explaining the public deficit forecast errors: results for the pool of all countries, all organizations (governments, EC, OECD) and all vintages $\left(\epsilon_{t+1}^{S_{t}}, \epsilon_{t+1}^{A_{t}}, \epsilon_{t+1}^{S_{t+1}}\right.$ and $\left.\epsilon_{t+1}^{A_{t+1}}\right)$.

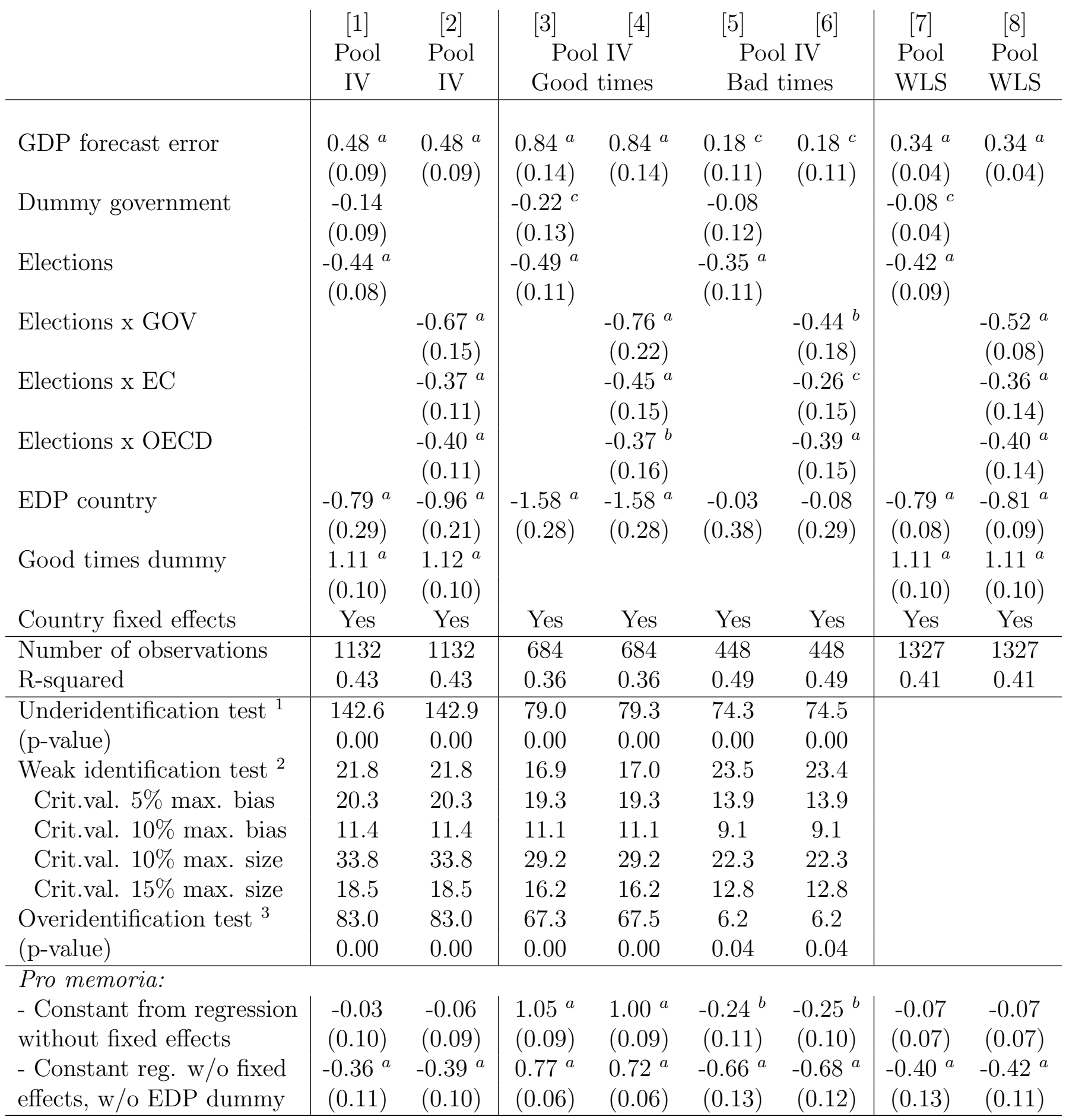

Notes: The dependent variable is the public deficit forecast error (actual minus forecast). Robust standard deviations of coefficient's estimates are reported in parentheses. ${ }^{a}$ Significant at $1 \%{ }^{b}{ }^{b}$ Significant at $5 \%{ }^{c}$ Significant at $10 \% .{ }^{1}$ Kleibergen-Paap rk LM statistic: the null hypothesis is that the equation is underidentified. ${ }^{2}$ Cragg-Donald Wald F statistic; Stock-Yogo weak ID test critical values: "max. bias" stands for maximal IV relative bias, and "max size" for maximal IV size. ${ }^{3}$ Hansen J statistic. 
Table 4: Explaining the public deficit forecast errors: results for each vintage of projections (pool of organizations and countries). Instrumental variables estimation.

\begin{tabular}{|c|c|c|c|c|}
\hline & $\epsilon_{t+1}^{S_{t}}$ & $\epsilon_{t+1}^{A_{t}}$ & $\epsilon_{t+1}^{S_{t+1}}$ & $\epsilon_{t+1}^{A_{t+1}}$ \\
\hline GDP forecast error & $\begin{array}{l}0.50^{a} \\
(0.12)\end{array}$ & $\begin{array}{l}0.42^{a} \\
(0.08)\end{array}$ & $\begin{array}{l}0.23^{c} \\
(0.12)\end{array}$ & $\begin{array}{l}0.38^{a} \\
(0.15)\end{array}$ \\
\hline Dummy government & & $\begin{array}{l}-0.05 \\
(0.15)\end{array}$ & $\begin{array}{l}-0.21^{c} \\
(0.12)\end{array}$ & $\begin{array}{c}0.02 \\
(0.06)\end{array}$ \\
\hline Elections & $\begin{array}{l}-0.29 \\
(0.22)\end{array}$ & $\begin{array}{l}-0.21 \\
(0.15)\end{array}$ & $\begin{array}{r}-0.58^{a} \\
(0.14)\end{array}$ & $\begin{array}{r}-0.32^{a} \\
(0.07)\end{array}$ \\
\hline EDP country & $\begin{array}{l}-0.79 \\
(0.59)\end{array}$ & $\begin{array}{c}-1.40^{a} \\
(0.46)\end{array}$ & $\begin{array}{l}-1.11^{a} \\
(0.30)\end{array}$ & $\begin{array}{r}-0.82^{a} \\
(0.25)\end{array}$ \\
\hline Good times dummy & $\begin{array}{l}2.00^{a} \\
(0.30)\end{array}$ & $\begin{array}{l}1.86^{a} \\
(0.16)\end{array}$ & $\begin{array}{l}0.71^{a} \\
(0.15)\end{array}$ & $\begin{array}{l}0.25^{a} \\
(0.06)\end{array}$ \\
\hline Country fixed effects & Yes & Yes & Yes & Yes \\
\hline Number of observations & 209 & 313 & 312 & 403 \\
\hline R-squared & 0.57 & 0.54 & 0.46 & 0.34 \\
\hline Underidentification test $^{1}$ & 81.2 & 129.9 & 28.9 & 41.0 \\
\hline (p-value) & 0.00 & 0.00 & 0.00 & 0.00 \\
\hline Weak identification test ${ }^{2}$ & 25.1 & 67.1 & 6.0 & 14.7 \\
\hline Crit.val. 5\% max. bias & 18.4 & 18.4 & 19.3 & 20.3 \\
\hline Crit.val. $10 \%$ max. bias & 10.8 & 10.8 & 11.1 & 11.4 \\
\hline Crit.val. $10 \%$ max. size & 26.9 & 26.9 & 29.2 & 33.8 \\
\hline Crit.val. $15 \%$ max. size & 15.1 & 15.1 & 16.2 & 18.5 \\
\hline Overidentification test ${ }^{3}$ & 31.75 & 25.32 & 24.84 & 20.81 \\
\hline (p-value) & 0.00 & 0.00 & 0.00 & 0.00 \\
\hline \multicolumn{5}{|l|}{ Pro memoria: } \\
\hline $\begin{array}{l}\text { - Constant from regression } \\
\text { without fixed effects }\end{array}$ & $\begin{array}{l}-0.40 \\
(0.30)\end{array}$ & $\begin{array}{c}-0.35^{b} \\
(0.17)\end{array}$ & $\begin{array}{l}0.30^{b} \\
(0.12)\end{array}$ & $\begin{array}{l}0.29^{a} \\
(0.07)\end{array}$ \\
\hline $\begin{array}{l}\text { - Constant reg. w/o fixed } \\
\text { effects, w/o EDP dummy }\end{array}$ & $\begin{array}{l}-0.83^{b} \\
(0.33)\end{array}$ & $\begin{array}{c}-0.83^{a} \\
(0.18)\end{array}$ & $\begin{array}{l}-0.03 \\
(0.14)\end{array}$ & $\begin{array}{l}0.12^{c} \\
(0.07)\end{array}$ \\
\hline
\end{tabular}

Notes: The dependent variable is the public deficit forecast error (actual minus forecast). Standard deviations of coefficient's estimates are reported in parentheses. ${ }^{a}$ Significant at $1 \%{ }^{b}$ Significant at $5 \%$; ${ }^{c}$ Significant at $10 \% .{ }^{1}$ Kleibergen-Paap rk LM statistic: the null hypothesis is that the equation is underidentified. ${ }^{2}$ Cragg-Donald Wald F statistic; Stock-Yogo weak ID test critical values: "max. bias" stands for maximal IV relative bias, and "max size" for maximal IV size. ${ }^{3}$ Hansen J statistic. 